\title{
Learning Media to Enhance Learning Motivation of Poor Fisherman Children in South Sulawesi Province
}

\author{
Jeanny Maria Fatimah \\ Department of Communication, Hasanuddin University, Makassar, Indonesia \\ Corresponding author: jeannyfatimah@gmail.com
}

\begin{abstract}
Learning media utilization have important role in every phase of learning process, so learning materials which taught by teacher need to be visualized in a more realize, especially to enhance learning motivation poor fisherman children in coastal area of South Sulawesi. Learning by using media can facilitate teacher in implementing transfer of knowledge and can achieve learning objection more efficient and effective. The problem is why learning media need to be utilized in learning process and method to design an effective learning media to enhance learning motivation of poor fisherman's children in coastal area. This research aims is to find and describe why learning media need to be utilized in learning process and how to design an effective method to enhance learning objection for poor fisherman's children in coastal area. To achieve that objection, researcher use case study approach as research method in order to understand research object and subject deeply in a frame of research result analysis. This research result show that the importance of learning media in learning process especially for poor fisherman's children because (1) poor fisherman's children tend to thing concretely, so the abstract learning materials can be visualize more realistic and proper, (2) learning media utilization can enhance the motivation and desire to stay learning then achieve understanding and produce positive values for the children. (3) Learning media help to transfer direct experience which is related to the real phenomena. The next is effective method to design learning media which simple, clear, and easy to understand and also proper to learning subject. Method of learning media uses simple material and easy to known or understand and provided in picture, audio and audiovisual.
\end{abstract}

Keywords-learning media, poor fisherman's children, learning motivation, coastal area

\section{INTRODUCTION}

Learning media is integral part of whole learning process. It means that learning media as one of component which is related to others component in order to provide expected learning situation. It has to use with relevant competence which needs to achieve and its own learning content. This function means that the utilization of media in learning has to pay attention on competence and learning materials.
The utilization of learning media has an important role in every learning process, so the teacher learning materials needs to be visualized in more realistic form, especially to enhance motivation of poor fisherman's children coastal area of South Sulawesi. Learning by using media makes the teacher easier to transfer knowledge and also can achieve learning objection effectively and efficiently. Learning system uses learning media to go through language utilization from abstract to more concrete and easy to understand.

For elementary school age which average is 6 to 13 years old with cognitive development separation. Overall elementary school child is classified into concrete operational phase. In this phase, child/student truly in the phase of realistic or concrete, and haven't understand an abstract thing. In this phase, child has an high egocentrism which implicate their mind cannot be drive or reversed.

Study which done by British Audio Visual Association (1995) about students perception estimate 75\% impression can be catch by touch senses, $6 \%$ from sense of smell and taste. If learning only by reading then accepted knowledge is about $10 \%$ and if learning only by audio will be accepted about $20 \%$. If we combine see and listening then accepted knowledge is about 50\%. Self experience and repeat in another opportunity can be accepted 90\%. Self experience trough media has level of accepted about $80 \%$ [1]. Therefore, if teacher in school learning can communicates or deliver message (knowledge, skills, and attitude) by using learning media or all the learning system component effectively the student learning output will be achieved optimally.

That is the case of fisherman's children in poverty circle that happened to their family needs a learning system which utilize learning media to enhance their learning motivation. Utilization of learning media can give real experience and put base of student development so their learning motivation and result better than before. However, it's not enough for teacher if they only have that competence, but there are other competences which must be mastered by them. For example, teacher competency in designing and using learning aids which can be known as learning media. If teacher has a good ability or competencies in designing and using learning media, 
it's will implicate to the learning process in classroom. Because utilization of good learning media can make the teacher easier in explaining learning materials then accelerate to achieve learning objective effectively and efficiently. The problem is why learning media needs to be utilized in learning processes and method to design an effective learning media to enhance learning motivation of poor fisherman's children in coastal area.

\section{RESEARCH METHOD}

This research uses constructivism paradigm. Constructivism paradigm uses qualitative method, mainstreaming the breadth and depth so make the researcher to learn about specific issues deeply and detail because data collection is not limited to only specific categories. Constructivism method utilizes case study approach to understand research object and subject deeply in process of research result analysis.

This research is located in poor fisherman's coastal area of South Sulawesi. Informant location is determined by cluster area. Informant quantity combines purposive technique and snowball for accurate informant in South Sulawesi, including two regencies namely Pinrang and Jeneponto. The next step is determine elementary school teacher as research subject which give learning trough communication media to the coastal area children. After that, data collection technique use in-depth interview. Instrument which use is researcher itself with focused group discussion, guide and in-depth interview.

After the data have already collected then analyzed tough three phase, namely explanation phase from researcher to the phenomena which is guided by academic ethics, synchronization phase between emik and ethic, and rationalization phase and also data abstraction.

\section{RESUlT AND DisCUSSION}

Learning media in enhancing motivation and consciousness poor fisherman's children have strong impact to the success of learning process. Utilization of learning media as series of program planning which include messages that must be communicated to student. Message is usually content of a learning topic. That message is communicated by teacher to children by media with the use of learning procedure which is known as method.

In modern learning system nowadays, student not only have role as communicant or message receiver, student can also act as communicator or message sender. In condition like that, then happen what called as two way traffic communication even multi way traffic communication. In form of learning communication needs media role to enhance level of effectiveness in achieving objective or competency. It means that, learning process will happen if there is communication between message receiver and source/ distributor of the message trough that media.
Learning media is always contained of two important aspects, namely hardware and message/software. So that, learning media needs hardware to provide message, but the most important is not the hardware but the message or learning information that is bring by media. Learning media is medium of the integration result from several components which have its own function with intention to achieve the learning objective. Learning media as a distributor of learning information, media also strongly effective and efficient to make the learning materials from abstract to concrete. Because the final target from the learning process for poor fisherman's children are formation of attitude and behavior of the student. The media objective is to visualize abstract concept into proper learning material for elementary school.

This research result also describes that as a learning information medium, media also effective and efficient to make the abstract learning material become concrete. Because the final target from the learning process are formation of attitude and behavior of the student. The media application needs to visualize an abstract concept that is learned by the student. But the main problem is because in the reality, teacher in elementary school in learning of many study subject find difficulties to use learning media. Choice of learning media forms and types according to Djamarah everything will depends on the teacher, including how the teacher pick right media based on the serious consideration so the learning process can achieve the objective in effective and efficient method [2]. It depends on teacher skills to pick and design right media. The effective media in achieving learning objective beside depends on teacher capability; it will describe several ways to design a ggo learning media.

Other findings revealed the need to use instructional media to improve the learning motivation of poor fisherman children in the classroom learning process, especially for elementary school students. The need of instructional media in learning process especially for poor fisherman children, because (1) poor fisherman children tend to still think concretely, so that abstract lesson material visualized more real and conformity, (2) use of learning media able to increase motivation and desire to stay study, gain understanding and give positive values in the child. (3) Learning media helps to transfer direct experience related to the actual event. Learning media does not serve as a means of entertainment, so it is not allowed to use it just for games or stimulate students' attention. Rather, provides to accelerate the learning process. This function implies that with the learning media students can catch the objectives and teaching materials easier and faster, improve the quality of teaching and learning process, as well as the motivation of learning poor fisherman children. Student learning result by using learning media will be long lasting so that the quality of learning has a high value.

In fact, other teachers are less interested in using learning media. In this context the teacher can be said to be a solid scholarship means that in implementing the learning process only rely on the knowledge and experience he found when in school without any effort to improve the quality of learning in 
accordance with the dynamics of the development of science and technology is growing today.

With these considerations, the use of effective methods for designing learning media through is a simple, clear and easy to understand, learning methodology design methodology, as well as the corresponding subject matter taught. Learning media design method uses simple and easy to know or understood material and presented in the form of picture, audio and audiovisual. So that the use of media in the process of learning in the classroom can have implications for several things, among others: the self itself, ie with the use of media can facilitate teachers in implementing the learning process in the classroom and self fisherman children, in the learning process can motivate them to learn more actively, innovatively, creatively, and fun.

With these considerations, the use of effective methods for designing learning media through is a simple, clear and easy to understand, learning methodology design methodology, as well as the corresponding subject matter taught. Learning media design method uses simple and easy to know or understood material and presented in the form of picture, audio and audiovisual. So the use of media in the process of learning in the classroom can have implications for several things, among others: the use of media can facilitate teachers in implementing the learning process in the classroom and self fishing students, in the learning process can motivate them to learn more actively, creative, and fun.

In a learning process, students are no longer seen as objects. In addition to being an object the student must also be treated as a subject in a learning process. The consequence of the statement is that teachers in giving learning materials to students should pay attention to the ability and desire of students. When teachers in the learning process view students as objects or clients solely, then the teacher still sees the function of the teacher as the holder of the highest authority of science and as indoctrinator.

\section{CONCLUSION}

The use of learning media to enhance the learning motivation of poor fisherman in South Sulawesi Province needs to be because (1) poor fisherman's children tend to still think concretely, so that the abstract subject matter is visualized more real and conform, (2) the use of learning media can increase motivation and desire to stay learning, gain understanding and give positive values in children. (3) Learning media helps to transfer the experience directly related to the actual event. Thus, the use of media in the process of learning in the classroom, especially for the elementary school-educated fisherman can imply on several matters, including: the teachers themselves, namely the use of media can facilitate teachers in implementing the process of learning in the classroom and for children of fishermen poor, in the learning process can motivate them to learn more actively, innovatively, creatively, and fun.

Because the important role of media in improving motivation to learn then to all parties concerned, especially those teaching in elementary school is advised to always use the media in the learning process because the use of media in the learning process can improve student creativity in terms of learning.

\section{ACKNOWLEDGMENT}

We would like to thank the provincial, regency, municipality governments in South Sulawesi, especially the primary schools in the districts that are the location of this research. Especially to the teachers who are very helpful in providing information for the advancement of education. Finally, to all those who contribute to this research process.

\section{REFERENCES}

[1] S. Malapu, Profesionalisme Guru dalam Upaya Meningkatan Potensi Peserta Didik. Mutu. Vol. VII. No.2 Edisi Juli-Desember 1998. Jakarta: Penerbit Dirjen Pendidikan Dasar dan Menengah Depdikbud, 1998.

[2] S.B. Djamarah, Prestasi Belajar dan Kompetensi Guru. Surabaya: Penerbit Usaha Nasional, 1994. 